\title{
DIE OUTEURSKAPVRAAGSTUK VAN DIE JOHANNESEVANGELIE MET DIE OOG OP INTERPRETASIE OF RESEPSIE
}

$A$ G van Aarde

\section{Inleiding}

Die pendulum in hedendaagse hermeneutiek, soos in die moderne literatuurwetenskap, het vanaf die outeur geswaai na die teks en vanaf die teks na die leser. Dit het egter nie by laasgenoemde punt absoluut tot stilstand gekom nie. Die pendulum beweeg teenswoordig binne die totale spektrum outeur-teks-leser, terwyl laasgenoemde baie aandag kry in 'n benadering wat soms bekend staan as leser-responskritiek of resepsie-estetika en ander kere "speechact"-teorie.

Vroeër is die klem in Bybelse hermeneutiek en eksegese geplaas op die outeur, sy invloed op en aanwending van bronne in die teks. Later is die klem as gevolg van die inwerking van die moderne semantiek en literatuurteorieë soos die Formalisme en die Strukturalisme verskuif na die immanensie van en die strukture in 'n teks. Belangrike insigte het uit beide periodes, die historieskritiese en die teksimmanente, vorendag gekom wat bruikbaar is op die gebied van teksinterpretasie, onder meer met betrekking tot verantwoorde kompetensie en beheersing van sowel die wording as die poëtiek van tekste en tekstipes. Die pendulum het egter verbybeweeg en die resepsie-estetika, in die gestalte van velerlei strominge ${ }^{11}$, beklemtoon dat die konkretisering van die betekenismoontlikhede van ' $n$ teks die resultaat is van ' $n$ relasionele wisselwerking tussen die teks (en sy vorm) en die leser.

Is die "outeur" die spreekwoordelike baba wat in hedendaagse hermeneutiek saam met die badwater weggegooi is? Indien dit die geval sou wees, is dit ' $n$ fout wat weer ingehaal sal moet word. En daarom is dit belangrik dat absolutismes in die hermeneutiek vermy moet word. Waar die teksanalitikus binne die histories-kritiese paradigma op grond van moderne literatuurwetenskaplike insigte bedag moet wees op literêre dwalings soos "intentional fallacy" en "referential fallacy", daar dreig ' $n$ ander gevaar weer binne paradigmas soos die Formalisme en die Strukturalisme. Dit is naamlik die moontlikheid dat teksoutonomie as beginsel oordrewe toegepas sal word. Die eksegeet is juis op grond van teksoutonomie as uitgangspunt attent gemaak op bogenoemde twee literêre dwalings. Met "intentional fallacy" word die oordeelsfout aangedui wat die eksegeet maak as hy reken dat hy sonder meer vanuit die wêreld van die teks na die bedoeling in die kop van die outeur as reële persoonlikheid buite die teks kan beweeg. Met "referential fallacy" word die fout aangedui wanneer die eksegeet sonder meer vanuit die wêreld van die teks wil beweeg na die historiese sosio-kulturele en godsdienstige konteks in die reële wêreld waarop die teks se wêreld betrekking het. 
'n Oordrewe toepassing van teksoutonomie as beginsel sou wees wanneer teksanalise ' $n$ analise van strukture ter wille van strukture ten koste van kommunikasie word. Die toepassing van die resente resepsie-estetika kan dit egter, hoewel nie noodwendig nie, verhelp. Insgelyks sal teksoutonomie, sowel as resepsie-estetika, te ver gevoer word as die toepassing daarvan sou meebring dat die funksie van die outeur as literêre konsep uit teksinterpretasie uitgeban word.

Die miskenning en selfs ontkenning van die literêre funksie van die outeur is aanwesig in die dwaling "affective fallacy" wat in die resepsieestetika soms voorkom. Dit word inderdaad aangetref in die sieninge van byvoorbeeld die "affektiewe kritikus" Stanley Fish"). "Affective fallacy" kom daarop neer dat die betekenismoontlikhede sowel as die estetiese literariteit van 'n teks so nou gekoppel word, dat dit selfs gelyk gestel word, aan die indruk wat die teks op die subjektiewe ervaring van 'n leser maak. Dit spreek vanself dat só 'n benadering die beperkthede "constraints" ophef wat die teks self en sy outeur op die interpretasie daarvan lê.

'n Teks weerspieël tog op een of ander wyse die outeur se bedoeling. ${ }^{31}$ En omdat dit so is dat die betekenismoontlikhede van 'n teks konkretiseer in die relasionele aktiwiteit tussen outeur, teks en leser, is die outeur se bedoeling een van daardie aspekte in die teks wat beperking lê op die leser se ervaring daarvan. En hoewel dit so is dat die outeur en die leser, soos uiteraard die teks self, in die teenswoordige literatuurwetenskap as literêre konstruksies beskou word wat nie sonder meer direk gelyk is aan die reële outeur en die reële leser nie, konkretiseer betekenis relatief tot onder andere ' $n$ bepaalde sosiokulturele en godsdienshistoriese konteks waarin outeur en leser hulle bevind. Dit bring mee dat teksinterpretasie onses insiens sinkronies bepaald is en nie diakronies nie, maar ook nie akronies nie. Dit bring egter ook mee dat die interpretasie van antieke tekste, soos Nuwe-Testamentiese tekste, waarvan die outeur, die leser en die sosiologiese konteks baie moeilik rekonstrueerbaar en dikwels onrekonstrueerbaar is, uitermate kompleks is.

Nog voordat Wolfgang Iser" meer as 'n dekade gelede tussen die reële leser buite die teks en die implisiete leser binne die teks begin onderskei het, het Wayne Booth ${ }^{5}$ reeds in 1961 die onderskeid tussen die reële outeur buite die teks en die implisiete outeur binne die teks getref. Hierdie parallel kan uitgebrei word: Soos een van die funksies van die implisiete leser dié is van identifikasiemedium tussen homself en onder andere die reële leser, so ook in die geval van die implisiete outeur. Laasgenoemde funksioneer met ander woorde nie net as "draer van waardes" "bundle of norms and values", soos Booth destyds gemeen het nie. Insgelyks ook nie net (volgens $H$ van den Bergh $)^{6}$ as 'n strateeg wat vanuit die perspektief van die derdepersoonvertelsituasie die leser manipuleer nie. Een van die funksies van die implisiete outeur is dié van identifikasiemedium tussen homself en onder andere die reële outeur. En hoewel die implisiete outeur in terme van die implisiete leser beskryf word, of omgekeerd, kan die resultate van so 'n beskrywing aangewend word om voelers na die buitetekstuele outeur, leser en hulle konteks, uit te steek. 
In die onderhawige artikel word ondersoek ingestel na die outeur van die Johannesevangelie, spesifiek met die oog op 'n volgende studie waarin die resultate geëksploiteer sal word met betrekking tot die interpretasie of resepsie van die Johannesevangelie. Vereers word die onderskeid tussen implisiete outeur en reële outeur buite rekening gelaat, maar later word hierdie onderskeid met die oog op terreinverkenning vir die volgende studie wel verdiskonteer. Die beoogde gebruik van die terme "interpretasie" en "resepsie" wat lyk asof dit hierbo en in die titel van die artikel, as alternatiewe funksioneer, sal ten slotte uitgespel word.

Dit is bekend dat die name van die outeurs van die vier kanonieke evangelies nie uit hulle geskrifte self bekend is nie, maar dat dit op oorlewering berus. Daar is in die verlede binne evangelienavorsing in hierdie verband veel klem daarop gelê dat ten minste Matteus en Johannes deel was van Jesus se twaalf dissipels, dat Markus die getuienis van Petrus aangebied het en dat Lukas ' $n$ reisgenoot van Paulus was. Hoewel Markus en Lukas dus geen ooggetuies was nie, kan Matteus en Johannes ten minste dan, volgens hierdie oorlewering, as ooggetuies beskou word. Wat die Johannesevangelie betref, wil hierdie vroeë kerklike tradisie eerstens dat die apostel Johannes, die seun van Sebedeus, die outeur sou wees en tweedens dat hy dieselfde persoon sou wees as die lieflingdissipel wat as karakter in hierdie evangelie optree.

In die artikel word die argument aangetoon waarop hierdie oorlewering berus. Ewenwel is die aantoon van hierdie argumente op sigself nie nuut in Johannese studies nie. Die bedoeling daarvan is om die tese te beredeneer dat die tradisionele opvatting nie bygedra het tot 'n adekwate interpretasie van die Johannesevangelie nie. Hierbenewens word die kontoere vir die beoogde studie aangedui waarin die siening bespreek sal word dat die lieflingdissipel as die geimpliseerde outeur van die Johannesevangelie funksioneer en dat die implisiete leser en ' $n$ waarskynlike godsdienshistoriese konteks in terme hiervan met die oog op die interpretasie van die Johannesevangelie beskryf kan word.

Om dié doelstelling te bereik, word daar in die artikel aan die volgende sake aandag gegee: (1) 'n kritiese evaluering van die argumente waarop die vroeë kerklike tradisie gebaseer word dat die apostel Johannes, die seun van Sebedeus, die Johannesevangelie sou geskryf het; (2) 'n kritiese evaluering van die teorie dat die lieflingdissipel in die Johannesevangelie dieselfde persoon sou wees as Johannes, die seun van Sebedeus; (3) die redes waarom Johannes, die seun van Sebedeus, nie die Johannesevangelie kon geskryf het nie; (4) ' $n$ toepassing en kritiese evaluering van Rudolf Bultmann se teorie ten opsigte van die outeurskap-vraagstuk; (5) 'n toepassing van die so genoemde Johannese skool-teorie; (6) ' $n$ kort analise van die teksinterne getuienis met betrekking tot die outeurskap van die Johannesevangelie; (7) 'n aanstip van die kontoere van 'n volgende studie oor die lieflingdissipel as die geïmpliseerde outeur van die Johannesevangelie met die oog op die interpretasie of resepsie daarvan. 


\section{Die vroeë kerklike tradisie}

Die tradisie dat die apostel Johannes, die seun van Sebedeus, te Efese, die Johannesevangelie geskryf het, word vir die eerste keer met sekerheid in ongeveer $180 \mathrm{nC}$ by Ireneüs in sy werk Adversus haereses III, 1, $2^{71}$ aangetref: epeita IOannes, ho mathëtess tou kuriou, ho kai epi to stethos autou anapesōn, kai autos exedōken to evangelion, en Efesō tès Asias diatribön. ${ }^{\prime \prime}$ Volgens W G Kümmel ${ }^{91}$ weerspieël Ireneüs se woorde sy tuistradisie in Klein-Asië, sowel as dié van Rome. Die volgende argumente is hiervoor 'n bewys: (1) Biskop Polukrates van Efese, in ' $n$ brief aan Viktor, die biskop van Rome (ongeveer $190 \mathrm{nCl}$, verwys na hierdie tradisie en meld onder andere: ${ }^{101}$ eti de kai lōannes ho epi to stēthos tou kuriou anapesōn, hos egenëthe hiereus to petalon peforekôs ( = "hy was 'n priester, draende 'n borsplaat" - A G v A), kai martus kai didaskalos. Houtos en Efesó kekoimètai ... ( = "hy is in Efese 'begrawe' " - A G v A); (2) Melito, biskop van Sardis, verwys op 'n soortgelyke wyse na die Johannesevangelie as na die Sinoptiese Evangelies; ( 3 ) in die Epistula aposto/orum, geskryf te Klein-Asië in ongeveer dieselfde tyd as die Johannesevangelie, word die Johannesevangelie nie net veelvuldig aangehaal nie, maar word Johannes ook heel eerste in die lys van die apostels vermeld; (4) wat die tradisie van Rome betref, kom die volgende uitspraak in die kanon van Muratori voor:11) "Die vierde van die evangelies, dié van Johannes, (een) van die dissipels: toe sy mede-dissipels en biskoppe hom (daartoe) versoek, het hy (Johannes) gesê: 'Vas vandag saam met my vir drie dae en wat aan elkeen van ons geopenbaar gemaak word, moet ons mekaar meedeel.' In dieselfde nag is aan Andreas, een van die apostels openbaar gemaak dat ... Johannes in sy eie naam alles moet neerskryf ... Daarom het hy (van homself) getuig ( kyk I Jh 1:1 - A G $\vee A$ ) as nie bloot 'n oog- en hoorgetuie nie, maar ook as 'n skrywer van al die wonders van die Here in volgorde".

Hoewel bogenoemde kerklike tradisie sedert die einde van die tweede eeu $\mathrm{nC}$ tot en met die opkoms van die historiese kritiek algemene aanvaarding geniet het, was dit gedurende die tweede helfte van die tweede eeu self nie die geval nie. Dit is daarom nodig om te weet waar Ireneüs aan sy inligting in verband met dié tradisie gekom het. Twee sake hieroor kan opgespoor word:

Eerstens, in 'n brief aan die gnostikus Florinus ${ }^{12)}$ maak Ireneüs melding van ' $n$ byeenkoms in Polukarpos se huis in Klein-Asië toe Ireneüs self maar nog ' $n$ kind was. Hy vertel dat hy 'n gesprek onthou wat Polukarpos met Johannes en ander oog- en hoorgetuies gevoer het. In sy brief aan die Filippense gee Polukarpos self egter geen aanduiding dat hy ooit kontak met die apostel Johannes gehad het nie.

Tweedens benewens bogenoemde vermelding van Ireneüs, beroep Ireneüs wat sy kennis in verband met Johannes betref, hom op bepaalde getuies van sekere presbuteroi dat hulle in Klein-Asië Johannes en van die ander apostels ontmoet het. ${ }^{13)}$ Behalwe dat Ireneüs op een ander plek ${ }^{14)}$ na hierdie presbuteroi verwys as mense in geselskap van Papias, 'n hoorgetuie van Johannes en 'n kameraad van Polukarpos \{Papias ho Iöannou men 
akoustès, Polukarpou de hetairos gegonōs), vind ons nóg in hierdie woorde van Ireneüs ' $n$ aanduiding dat Johannes die skrywer is van die Vierde Evangelie nóg in enige ander tradisie van die presbuteroi inligting in verband met Johannes. Dit is buitendien onseker wie hierdie presbuteroi in werklikheid was.

Wie is dié Johannes na wie bogenoemde tradisie wat as Ireneüs se bron gedien het, verwys en wat word bedoel met die verwysing dat Papias 'n tydgenoot was van sowel die genoemde presbuteroi as van Ireneüs self?

Wat die betrokke Johannes betref, word die persoon in die onderhawige tradisie slegs gekwalifiseer as mathètēs tou Kuriou. Geen melding word egter gemaak dat dié Johannes in Klein-Asië sou gewoon en daar as die skrywer van die Vierde Evangelie sou bekend gestaan het nie. Dit is dus nie moontlik om die Johannes na wie Ireneüs verwys, met die skrywer van die Johannesevangelie te identifiseer nie.

Wat Ireneüs se verwysing na Papias betref, moet ons in gedagte hou dat feitlik geen direkte inligting van Papias self vandag meer beskikbaar is nie, maar dat dit sekondêr is, meestal via Eusebius. Die enigste werk van Papias in hierdie verband is ' $n$ Latynse proloog tot die Johannesevangelie waarvolgens Papias die Vierde Evangelie na Johannes as skrywer sou terugvoer. Hierdie proloog is egter 'n totale korrupte en wat datering betref, onsekere teks. Dit is derhalwe onbruikbaar om enige informasie in verband met die skrywer van die Johannesevangelie in te win. By Eusebius self vind ons ook geen inligting oor Papias in verband met die Johannesevangelie nie. Wanneer daar na Eusebius se sitering van Papias gekyk word, dan vind ons dat, in teenstelling met Ireneüs se verwysing na Papias as Ióannou akoustēs, Papias self sêt ${ }^{15)}$ dat hy nie 'n oor- en hoorgetuie was nie. Volgens dié sitaat ${ }^{16)}$ het Papias navrae gedoen by dié wat hy noem, "navolginge van die presbuterol" en sodoende die tradisies van die presbuteroi self ondersoek om agter te kom wat die apostels (ingesluit die apostel Johannes) en die twee "dissipels van die Here" Itou Kuriou mathètail, naamlik Aristion en die presbuteros Johannes, gesê het.

Papias, soos aangehaal deur Eusebius, maak dus van twee Johannesse melding: die een word geassosieer met die Twaalftal en lewe, net soos die ander, waarskynlik nie meer tydens Papias se skrywe nie; die ander een, met die benaming presbuteros Ioannès,! lewe net soos Aristion waarskynlik wel tydens Papias se skrywe. Die benaming presbuteros word blykbaar hier as tegniese term gebruik om die begrip "draer van die apostoliese tradisie" aan te dui. Volgens Kümmel ${ }^{17}$ ' kan die kwalifisering van die presbuteros Johannes en Aristion as hoi tou Kuriou mathètai opgeneem word as "persoonlike dissipels" wat nie tot die kring van die Twaalf behoort het nie. Die enigste gevolgtrekking wat ons op grond van die Papias-sitaat kan maak, is enersyds dat Papias nie self 'n hoor- en ooggetuie was nie en andersyds dat hy die apostoliese tradisie via die "volgelinge" van die presbuteroi verneem het. Wat die identiteit van die skrywer van die Johannesevangelie betref, sê Papias egter niks.

Daar bestaan wel die moontlikheid, hoewel bloot ' $n$ moontlikheid, dat die Johannesevangelie en die Johannesbriewe die werk van dieselfde skrywer 
is. Hierdie moontlikheid word op die volgende drie oorweginge gebaseer: (1) Ireneüs verwys na die skrywer van die Johannesevangelie as mathètēs tou Kuriou en gebruik hierdie uitdrukking vir geeneen van die ander apostels nie; (2) Papias noem onder andere die presbuteros Johannes ook tou Kuriou mathētēs; (3) Die Skrywer van die 2 Johannesbrief (1:2) en 3 Johannesbrief $11: 2)$ noem homself ook ho presbuteros. Dit is egter meer waarskynlik dat die Johannesevangelie, sowel as die Johannesbriewe, beskou moet word as produkte van die literêre aktiwiteit van die so genoemde "Johannes-skool" (kyk later).

Die teorie dat die apostel Johannes, die seun van Sebedeus, dieselfde persoon is as die "lieflingdissipel" in die Johannesevangelie

Op grond van 'n vergelyking tussen die Johannesevangelie en die Sinoptiese Evangelies word daar deur sommige persone afgelei dat die so genoemde "lieflingdissipel" in die Johannesevangelie een van die twee seuns van Sebedeus (Johannes of Jakobus) was van wie ons in die Sinoptiese Evangelies lees. Hierdie afleiding word dan ingespan as argument om aan te toon dat Johannes, die seun van Sebedeus, die skrywer is van die Johannesevangelie. Die volgende oorweginge geld gewoonlik in hierdie verband:

(1) Daar word aangeneem dat die "lieflingdissipel" deel moes wees van die kleiner kring in die Twaalftal, naamlik Petrus en die seuns van Sebedeus (Johannes en Jakobus) - vergelyk Mk 5:37 par; 9:2 par; 14:33 par. (2) Omdat Petrus en die "lieflingdissipel" naasmekaar in die Johannesevangelie gestel word en omdat Jakobus reeds in $44 \mathrm{nC}$ gesterf het, word daar afgelei dat die "lieflingdissipel" dieselfde persoon moes wees as Jakobus se broer, dit wil sê Johannes. (3) Bogenoemde afleiding word na bewering bevestig deur die Johannese weergawe van die roeping van die dissipels in $\mathrm{Jh} 1: 35-51$ in vergelyking met dié in Mk 1:16-20. Die volgende inligting word dan op grond van hierdie vergelyking bekom: (i) Volgens $\mathrm{Jh}$ 1:35-39 het twee dissipels van Johannes die Doper Jesus begin volg. (ii) Volgens Jh 1:40 was een van dié twee dissipels Andreas wat volgens vss $41 \mathrm{v}$ sy broer Petrus na Jesus toe gebring het. In die beste manuskripte kom die bywoord prōton voor in verband met Andreas se vind van sy broer. (Ander manuskripte lees òf prōtos òf prö of selfs ander moontlikhede.) Op grond van die voorkoms van hierdie bywoord word afgelei dat dit kronologies dui op Andreas se bring van sy broer Petrus na Jesus toe wat vobr 'n ander, maar soortgelyke handeling plaasgevind het. Hierdie ander handeling kom dan van die (anonieme) dissipel wat, soos in die Johannesevangelie berig, net soos Andreas eers ' $n$ dissipel van Johannes die Doper was en, weer net soos Andreas, sy broer na Jesus toe gebring het. Laasgenoemde word egter nie deur die Johannesevangelie vertel nie; dit is 'n stelling wat na bewering sy grond vind in Markus se weergawe van die roeping van die dissipels. (iii) Volgens Mk 1:16-20 was die eerste dissipels die broerpare Andreas-Petrus en Johannes-Jakobus. Op grond hiervan word afgelei dat bogenoemde anonieme dissipel in die Johannesevangelie dieselfde per- 
soon is as Johannes, die een seun van Sebedeus en dat hy, nadat Andreas eers sy broer na Jesus toe gebring het, sý broer Jakobus gebring het. baar nie:18)

Bogenoemde teorie is op grond van die volgende besware nie aanvaar-

(1) Dit is op grond van sinkroniese en saaklike oorweginge nie aanvaarbaar om die Johannesevangelie vanuit die Sinoptiese Evangelies te verklaar nie. Paul Minear ${ }^{19}$ ' maak die volgende, hoewel in ' $n$ ander verband, relevante opmerking: "Much misinterpretation of this gospel" (die Johannesevangelie - A G v A) "stems from a hasty reading of it in the light of our prior knowledge of the Synoptics." (2) Die afleiding dat die "lieflingdissipel" tot die Sinoptici se "kleiner dissipelkring" moes behoort, is uiters aanvegbaar. (3) Indien aanvaar sou word dat die "lieflingdissipel" dieselfde persoon is as Johannes, die seun van Sebedeus, is die verskynsel in die Johannesevangelie dat die "lieflingdissipel" eers vanaf Jh 13 'n rol begin vervul terwyl hy van die aanvang van die evangelie af een van Jesus se dissipels was, baie problematies en in der waarheid onverklaarbaar. Eweneens is dit onverklaarbaar waarom Johannes, die seun van Sebedeus, die benaming "lieflingdissipel" in die Johannesevangelie sou hê.

Die redes waarom Johannes, die seun van Sebedeus, nie die Johannesevangelie kon geskryf het nie

Op grond van die volgende argumente is dit nie moontlik dat Johannes, die seun van Sebedeus, die skrywer van die Johannesevangelie is nie: ${ }^{20}$ ) Die afhanklikheid van Markus (vgl. bv. die passie-vertelling in die Johannesevangelie) en ook op sommige plekke in die Johannesevangelie van Lukas, ${ }^{21}$ wat nie direkte oog- en hoorgetuies was nie, deur een van die Twaalftal is moeilik aanvaarbaar.

Die tipiese Johannese skematisering van Jesus se strydgesprekke met "die Jode" is nie 'n verwysing na die werklike opposisie in die tyd van die historiese Jesus van die kant van die Fariseërs, Sadduseërs en Skrifgeleerdes nie. ${ }^{22)}$

Al die insidente in die Sinoptiese Evangelies waar Johannes, die seun van Sebedeus, ' $n$ prominente rol vervul, is in die Johannesevangelie afwesig: (1) Die roeping van die seuns van Sebedeus (Mk 1:19-20 par); (2) Die genesing van Petrus se skoonma (Mk 1:29 par); (3) Die kies van die Twaalf (Mk 3:13- 19 par); (4) Die opwek van Jaïrus se dogtertjie uit die dood (Mk 5:37 par); (5) Die verheerliking op die berg (Mk 9:2-8 par); (6) Die versoek van die seuns van Sebedeus met die voorspelling van hulle martelaarskap (Mk 10:35-45 par); (7) Die Getsemane-episode (Mk 14:32-42 par).

Jakobus, die broer van Johannes, word nooit in die Johannesevangelie vermeld nie.

Volgens $\mathrm{Hd}$ 4:13 was Petrus sowel as Johannes anthropio agrammatoi, terwyl die Johannesevangelie in goeie Semitiserende Grieks geskryf is.

Indien die volgende aanduidinge dat Johannes, die seun van 
Sebedeus, 'n vroeë marteldood gesterf het, aanvaar word (wat egter nie bo alle twyfel moontlik is nie), kan Johannes as skrywer van die Johannesevangelie uitgesluit word: (1) Mk 10:39 par - "Die beker wat Ek drink, sal julle (Jakobus en Johannes, volgens vs 35 - A G v A) drink, ja, en met die doop waarmee Ek gedoop word, sal julle gedoop word"; (2) Volgens sekere baie laat berigte het Papias die tradisie oorgelewer dat Johannes, die teoloog en sy broer Jakobus doodgemaak is deur die Jode; (3) Sommige ou lyste van martelare vermeld ook Johannes se martelaarskap.

Die tipe taalgebrui! van die Johannesevangelie is nie die taal van alleen die Palestynse Jodedom nie. Dit kan eerder as Semitiserende Grieks beskryf word. ${ }^{23)}$ Hierdie tipe taalgebruik kan breedweg ook as dié van die Sinoptiese Evangelies beskou word. ${ }^{24)}$ Die taalgebruik van die Johannesevangelie verskil egter radikaal van dié in die Sinoptiese Evangelies. So byvoorbeeld is die taalgebruik van die Johannese Jesus, afgesien van Mt 11:27 ("My Vader het alles aan My toevertrou, en niemand ken die Seun nie, behalwe die Vader; en ook ken niemand die Vader nie, behalwe die Seun en elkeen aan wie die Seun Hom wil bekend maak") wat Kümme|25) die "alten Wort" noem, nie dié van die Sinoptici se Jesus nie. Hierdie en ander gewigtige argumente wat op taal en styl gegrond is, ${ }^{26)}$ maak die skrywe van die Johannesevangelie deur 'n oogen hoorgetuie onmoontlik.

Net soos die Sinoptiese Evangelies, word die Johannesevangelie vandag as die eindproduk van ' $n$ lang en gekompliseerde ontwikkelingsproses gesien. Dit bevat materiaal wat oorgelewer, deur die outeur versamel en met sy eie teologiese bedoeling gerangskik is. Só gesien, behoort sekere aspekte van Rudolf Bultmann se teorie ten opsigte van die outeurskap van die Johannesevangelie en die funksionering van die "lieflingdissipel" as ' $n$ "ideale figuur" herwaardeer te word.

\section{Rudolf Bultmann se teorie ten opsigte van die outeurskap van die Johannesevangelie}

Dit is vir Bultmann 'n uitgemaakte saak dat die outeur van die Johannesevangelie nie 'n oog- en hoorgetuie was nie. Inteendeel, die evangelis was van bronne afhanklik. Volgens Bultmann ${ }^{27}$ moet die Johannesevangelie gelees word teen 'n laat-eerste eeuse Palestynse en Siriese agtergrond. Sowel die evangelis as die vroeë kerklike kring van waaruit hy kom, moet derhalwe teen dieselfde agtergrond beskou word en veral teen die agtergrond van die teenwoordigheid van die so genoemde Johannes die Doper-groep. Die feit van die bestaan van só 'n groep en veral dié van die voortbestaan daarvan ná die dood van Johannes die Doper, blyk uit gedeeltes soos Jh 1:6-8; 1:15; 1:19-51 en 3:22-30, asook $\mathrm{Hd}$ 18:25 en 19:1-7. Aanduidinge van polemiese en apologetiese motiewe teen hierdie Johannes die Doper-groep kom in die Johannesevangelie (sowel as in ander literatuur soos Pseudo-Klemens) voor. Dit wil voorkom asof ten minste 'n deel van dié groep na die vroeg-Christelike gemeente oorgegaan het. Dit kan gesien word in onder andere die Johannese 
weergawe van die roeping van die dissipels waarin vertel word dat die eerste twee dissipels voorheen dissipels van Johannes die Doper was. Die Johannese beklemtoning dat Johannes die Doper self sê dat Jesus meer is as hy, moet dan ook teen die agtergrond van die vermelde konkurrensie gelees word.

Volgens Bultmann is bogenoemde polemiese motiewe egter nie die enigste wat ' $n$ rol by die skrywe van die Johannesevangelie gespeel het nie. 'n Tendens teen die Joodse Christendom ten gunste van die heiden-Christendom is volgens hom ' $n$ ander sodanige motief. Die teenwoordigheid en historiese funksie van die "lieflingdissipel" in die Johannesevangelie verkry sy reliëf teen die agtergrond van laasgenoemde tendens. Volgens hierdie teorie is die "lieflingdissipel" nie 'n "historiese figuur" nie, maar 'n "geïdealiseerde figuur". Die evangelis identifiseer hom met hierdie figuur wat die heidenChristendom verteenwoordig. Bultmann beklemtoon egter dat die evangelis hom nie identifiseer met die historiese persoon as sodanig van die "lieflingdissipel" nie, maar alleen in die mate waarin hy hom met die heidenChristendom identifiseer: "Will sich der Evg list selbst in dieser Gestalt (dié van die 'lieflingdissipel' - A G v A) darstellen? In gewisser Weise wohl, soferr er eben in sich das Selbstbewusstein und Überlegenheitsgefühl des freien Heidenchristentums trägt. Aber nicht seine Person, sondern seine Sache wird durch en Lieblingsjünger repräsentiert." 28)

Soos die "lieflingdissipel" die heiden-Christendom verteenwoordig, so verteenwoordig Petrus volgens hierdie teorie die Joodse Christendom. Dié opposisionele tendens en die identifisering van die evangelis met die "lieflingdissipel" blyk volgens Bultmann uit gedeeltes soos onder andere Jh 13:21-30, 19:26 en 20:2-10, asook 21:7 en 21:20-23. In die eerste passasie maak Jesus die voorafaankondiging dat Judas Iskariot Hom gaan verraai, terwyl die "lieflingdissipel" langs Jesus sit en die vrae-werk doen. In Jh 19:26 wys Jesus tydens sy kruisiging sy ma toe aan die sorg van die "lieflingdissipel". Die "ma" hier is, soos Petrus elders, die verteenwoordiging van die Joodse Christendom. In Jh 20:2-10. die Johannese weergawe van die lee graf, vind ons dat die "lierıngdissıpel" (ho alios mathetes) vinniger na die graf toe hardloop as Petrus en dat hy "sien en glo". Soos ons reeds aangedui het, vind ons dieselfde opposisionele tenders in Jh 21:7 en 21:20-23.

Bultmann se teorie in verband met wie onder andere die "lieflingdissipel" en Petrus in die reële wêreld tydens die skrywe van die Johannesevangelie sou verteenwoordig, is uiteraard 'n buitetekstuele aangeleentheid wat nie net uit teks-interne getuienis bevestig kan word nie. Net soos die vraag wie die reële skrywer van die Johannesevangelie sou wees, is dié verband met bogenoemde verteenwoordiging ' $n$ historiese vraagstelling wat deur middel van onder andere ' $n$ vergelykende teksondersoek met betrekking tot korrelerende gegewenhede uitgevoer moet word. In dié opsig is Bultmann se mening in der waarheid net so hipoteties, hoewel nie heeltemal so onwaarskynlik nie, as dié dat Johannes, die seun van Sebedeus, die reële skrywer van die Johannesevangelie sou wees. Bultman se bydrae in verband met die 
Johannesevangelie se outeurskapvraagsstelling is dat hy die teenwoordigheid van die "lieflingsdissipel" nie as aanduiding van outeurskap as sodanig sien nie, maar 'n teorie ontwerp oor die "lieflingdissipel" se literêre (en historiese) funksie as karakter en die identifikasie van die reële outeur met hierdie karakter en ander karakters in die Johannesevangelie, soos Jesus se ma.

\section{Die Johannes skool-teorie met betrekking tot die outeurskap van die Johannese geskrifte}

Die kwessie in verband met die identiteit van die reële outeur van die Johannesevangelie het geblyk minder belangrik te wees, inagnemende die groeiende besef dat die evangelie moontlik die produk was van 'n antieke skoolaktiwiteit. Hiertoe het Bultmann se literêre teorie met betrekking tot die Johannesevangelie baie bygedra. Bultmann het onder andere beweer dat naas bronne, daar 'n "outeur" was en ten slotte 'n "kerklike redaktor". Volgens D M Smith kry Bultmann se "literarkritische" analise verdere ondersteuning wanneer dit gekombineer word met 'n ander teorie, dié van die so genoemde "Johannese skool" as die "sosiologiese konteks" van die Johannese geskrifte: "There are, in fact, good reasons for suggesting that John emerged from a school or circles of early Christianity in which distinct traditions and a characteristic perspective on the gospel were preserved and fostered." 29 )

Die Johannese briewe veronderstel só 'n Johannese gemeenskap wie se welsyn deur die "outeur" van die briewe as sy verantwoordelikheid beskou word. Op grond van verskille in styl en teologiese terminologie en perspektiewe, kan hierdie "outeur" nie dieselfde persoon wees as die "outeur" van die Johannesevangelie nie. ${ }^{30}$ ) Omdat die "outeur" van die Johannesbriewe nie die "outeur" is van die Johannesevangelie nie, is dit 'n vraag hoe die ooreenstemmende taalgebruik, styl en temas wat wel in beide korpusse aangetref word, verklaar moet word. R A Culpepper toon oortuigend aan dat die bestaan van ' $n$ "Johannese skool" die beste verklaring is. Die volgende argumente word hiervoor ingespan: ${ }^{31}$ )

Die ooreenkomste van verskille in taalgebruik en die verwantskap en onderskeid in teologiese inhoud tussen die Johannesevangelie en die Johannesbriewe kan die beste verklaar word indien ons aanneem dat hierdie korpusse die produkte is van verskillende outeurs wat deel gehad het aan dieselfde skoolaktiwiteit. Wat in hierdie verband opvallend is, is dat die tipiese taalgebruik van die "outeur" van die Johannesbriewe dikwels dié is wat in die Johannesevangelie in die mond van Jesus voorkom. Vergelyk byvoorbeeld die volgende uitsprake: ${ }^{32)}$

"Ons weet dat ons klaar uit die dood na die lewe oorgegaan het, want ons het ons broers lief. Wie nie liefhet nie, bly in die dood" (I Jh 3:14). "Dit verseker Ek julle: Wie luister na wat Ek sê ..., het die ewige lewe. Hy word nie veroordeel nie maar het reeds uit die dood na die lewe oorgegaan" (Jh 5:24). 
"Dit is die boodskap wat julle van die begin af gehoor het: Ons moet mekaar liefhê (Jh 3:11).

"Ek gee julle 'n nuwe gebod: julle moet mekaar liefhê" (Jh 13:34).

Wat verskille betref, is die betekenisvolle verskuiwing in die gebruik van die woord archē 'n goeie voorbeeld. In die Johannesevangelie word hierdie woord gebruik in verband met die pre-eksistensie van die Logos en in die I Johannesbrief in verband met die aanvang van die betroubare tradisie. Nieteenstaande die verskil in verwysing, is die verwantskap in teologiese inhoud tog opvallend: die lyn van die betroubare tradisie vanaf die Vader na die Seun, gekontinueer deur die "apostoliese" garant.

Die patristiese literatuur (kyk hierbo: die vroeë kerklike tradisie) suggereer baie sterk die moontlikheid van die bestaan van ' $n$ Johannese skool.

Die bepaalde wyse waarop die Ou Testament in die Johannesevangelie gebruik word, is ' $n$ aanduiding dat die evangelie waarskynlik die literêre produk is van 'n skool-aktiwiteit.

Die Johannese geskrifte reflekteer ongetwyfeld 'n gemeenskap met eienskappe wat ook in ander antieke skole (soos dié van Hillel, van Philo, dié te Qumran, Stoa, ensovoorts) voorkom. Voorbeelde van hierdie eienskappe is (i) die voorkoms van bepaalde aanspreekvorme wat op ontvangers in dié tipe skole dui: hoi filoi, tous adelfous, mathetai, tekna en agapētoi; (ii) die klem wat gelê word op "broederskap", soos uitgedruk in onder andere die metafore "die lote van 'n druiwestok" en "skape in 'n kraal", asook terme soos koinōnia.

Die figuur van die "lieflingdissipel" in die Johannesevangelie se posisie in die "werklike wêreld" moet waarskynlik in die Johannese skool gesoek word. Hierdie posisie is in velerlei opsigte enigmaties. Hy staan waarskynlik in 'n bepaalde verhouding met die presbuteros wat die Johannesbriewe geskryf het ên met die "Parakleet", dié "medium" van die gekontinueerde teen-

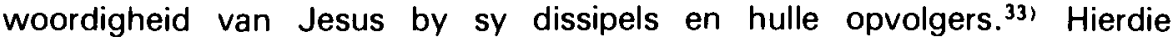
verhouding kan op grond van die volgende vrae as "enigmaties" beskryf word. ${ }^{34)}$

Waarom was dit nodig om in hoofstuk 21 'n foutiewe, beweerde berig van Jesus oor die "lieflingdissipel" reg te stel? Na bewering sou Jesus gesê het dat hierdie dissipel nie sou sterf nie en volgens Jh 21:23 het Jesus op 'n vraag van Petrus gesê dat as Hy sou wou hê dat die "lieflingdissipel" tot by die wederkoms moet lewe, gaan dit Petrus nie aan nie. In Jh 21:24 word gesê dat hierdie dissipel die evangelie geskryf het en dat sy "getuienis" (marturia) "waar" (a/êthēs) is. Vind ons hier 'n riglyn hoe die Johannesevangelie gelees moet word?

Was die "lieflingdissipel" 'n wyd-erkende leier onder die historiese lesers van die Johannesevangelie? Sy bevoorregte posisie met betrekking tot Jesus in die evangelie - sedert die "laaste pasga" (kyk Jh 13:23) was hy altyd na aan Jesus - dui sterk in hierdie rigting.

Watter situasie moet in die Johannese gemeentekring veronderstel 
word wat as verklaring kan dien vir die verskynsel in die Johannesevangelie dat die "lieflingdissipel" uitgebeeld word as iemand in opposisie met Petrus, die wyd-erkende leier onder die vroeë Christene? Die feit dat Petrus met betrekking tot hierdie opposisie altyd die tweede beste daarvan afkom, maak hierdie vraag nog moeiliker.

Op hierdie stadium van ons studie het dit nodig geword om skerp tussen bepaalde kategorieë onderskeid te begin tref: eerstens, ter wille van die vermyding van "referential fallacy", tussen binnetekstuele en buitetekstuele sosio-historiese verwysing; tweedens, ter wille van die vermyding van "intentional fallacy," tussen die reële outeur buite die teks en die implisiete outeur binne die teks. Ons bepaal ons vervolgens in 'n kort analise van teksinterne getuienis by laasgenoemde kategorieë.

Teksinterne getuienis van die Johannesevangelie met betrekking tot outeurskap

\section{Johannes $\mathbf{1}-\mathbf{2 0}$}

Hoewel die "outeur" van die Johannesevangelie soms na hom self, saam met ander, verwys as "ons" (Jh 1:14 en 1:16), sè hy in hierdie gedeeltes, asook in die res van hoofstukke $1-20$, nie dat hy dieselfde persoon is as Johannes, die seun van Sebedeus nie of dat hy 'n oog-en hoorgetuie is nie.

Wat hoofstukke 1-20 verder betref, wil dit uit die konteks van Jh 19:25-35 ('n deel van die kruisiging-episode) lyk dat die "outeur" die leser wil laat verstaan dat daar saam met die vroue (Jesus se ma, Maria en sy ma se suster, Maria, die vrou van Klopas, asook Maria Magdalena) 'n dissipel by die kruisiging-gebeure teenwoordig was, naamlik die "lieflingdissipel". Dit lyk met ander woorde dat die "outeur" te kenne wil gee dat hierdie dissipel 'n ooggetuie van ten minste die kruisiging-gebeure was (vgl Jh 19:35a - ho heōrakōs memarturēken) ên dat sy getuienis "waar" is (vgl Jh 19:35b - alēthinē autou estin hè marturial.

Hoewel die "lieflingdissipel" - of soos hy ook in die Johannesevangelie genoem word: "die ander dissipel" (Jh 18:15,16; 20:2,3 en 8) in Jh 18:15 en 16 beskryf word as iemand wat die hoëpriester Kajafas geken het, word sy identiteit nie by bogenoemde kruisiging-gebeure of elders in die Johannesevangelie (Jh 13:23-25; 19:26v) bekend gemaak nie. Die enigste gevolgtrekking wat voorlopig gemaak kan word op grond van die teksinterne getuienis in hoofstukke $1-20$, met die oog op die beoogde studie waarna ons in die inleiding tot die artikel verwys het, word in die volgende uitspraak van Kümme| ${ }^{35 \text { ' }}$ saamgevat: "Deutlich ist nur, dass diese Lieblingsjünger mit Petrus in irgendeinem Konkurrenzverhältnis steht."

\section{Johannes 21}

In Jh 21 word geen aanduidinge aangetref wat kan help in die identifisering 
van die "lieflingdissipel" nie, ten spyte daarvan dat daar na hom in hierdie hoofstuk verwys word as die "outeur" van die hele Johannesevangelie.

Hoewel hoofstuk 21, tekskrities gesien, saam met die res van die Johannesevangelie oorgelewer is, word algemeen aanvaar dat dit op grond van saaklike en letterkundige oorwegings nie die werk van een en dieselfde "outeur" is nie. H Thyen ${ }^{36)}$ en $M$ de Jonge, ${ }^{37)}$ onder andere, meen dat hoofstuk 21 eerder gesien moet word as ' $n$ goed geredigeerde epiloog en nie bloot as ' $n$ aanhangsel wat inligting bevat wat slegs betrekking sou hê op 'n bepaalde latere stadium in die redaksiegeskiedenis van die Johannesevangelie nie. P S Minear ${ }^{38)}$ gaan nog verder en voer stewige gronde aan waarom hoofstuk 21 hoegenaamd nie beskou moet word as die produk van die finale redaktor nie (kyk Bultmann se siening hierbo), maar as dié van die redaktorverteller wat vir die hele Johannesevangelie verantwoordelik was. Sonder om op die vraagstuk in verband met hoofstuk 21 se geskiedenis en funksie in die Johannesevangelie hier in te gaan, is dit vir die doel van die onderhawige studie genoegsaam om minstens van die feit uit te gaan dat ' $n$ soort literêre verwantskap tussen hoofstukke $1-20$ en hoofstuk 21 bestaan. Dit kan veral gesien word in die naasmekaar, opposisionele plasing van die "lieflingdissipel" en Petrus (vgl. veral Jh 21:7 - "Die dissipel vir wie Jesus baie lief was, sê toe vir Petrus: 'Dit is die Here!' ", asook Jh 21:20-23 - "Toe Petrus omdraai, sien hy die dissipel volg vir wie Jesus baie lief was, wat ook by die maaltyd na Jesus se kant toe oorgeleun en gevra het: 'Here, wie is u verraaier?' (Jh 13:23 - A G v A). Toe Petrus hom dan sien, vra Petrus vir Jesus: 'Here, en wat van hom?' Jesus antwoord hom: 'As Ek wil hê dat hy in die lewe moet bly totdat Ek weer kom, is dit nie jou saak nie. Volg jy My!' Die gerug het toe onder die broers versprei dat daardie dissipel nie sal sterwe nie ... maar: 'As Ek wil hê dat hy in die lewe moet bly totdat Ek weer kom, is dit nie jou saak nie.'

Afgesien van die verwysing na Jh 13:23 deur die "outeur" van hoofstuk 21 , is die tendens met betrekking tot die opposisie tussen Petrus en die "lieflingdissipel" wat ook in hoofstukke 1-20 aanwesig is (kyk bovermelde uitspraak van Kümmel), ook in hoofstuk 21 sonder twyfel aanwysbaar. Die "outeur" van hoofstuk 21 kon egter nie dieselfde persoon wees as die "lieflingdissipel" nie. Die rede hiervoor is onder andere daarin geleë dat dit op grond van die opgestane Jesus se enigmatiese woorde aan Petrus oor die beweerde onsterflikheid van die "lieflingdissipel" (Jh 21:20-23), implisiet duidelik is dat die "lieflingdissipel" intussen met betrekking tot die tyd van die skrywe van hoofstuk 21 , reeds dood was. ${ }^{39}$ )

Hoe moet Jh 21:24a dan verklaar word: "Dit is die dissipel (die 'lieflingdissipel' - A G $\vee$ Al wat oor al hierdie dinge getuienis aflê en dit beskrywe het, en ons weet dat sy getuienis waar is"? Hier word die "lieflingdissipel", net soos in die geval van Jh 19:35, as ooggetuie en as "outeur" van die Johannesevangelie aangedui: ho marturōn peri toutōn kai grapsas tauta. (Die woordjie tauta verwys na alle waarskynlikheid, net soos peri toutōn, na die hele Johannesevangelie, hoofstuk 21 ingesluit. $)^{40)} \mathrm{Jh} 21: 24 \mathrm{~b}$ voeg eweneens soos $\mathrm{Jh}$ 19:35b toe: kai oidamen hoti alēthès autou hè marturia estin. Deur met betrek- 
king tot hierdie verwysings te onderskei tussen erzäh/te Zeit en besprochene Zeit, word die volgende rakende die outeurskap-vraagstuk aan die lig gebring:

Die oorgang vanaf "vertelde tyd" in Jh 21:23 na "vertellerskommentaar" in Jh 21:24v is opmerklik. Met ander woorde, tot en met vs 23 is die verteller vertellend aan die woord en vanaf vs 24 lewer hy as verteller kommentaar op die vertelde gebeure en verskaf hy vir die leser addisionele inligting en norme hoe die vertelling gelees moet word. Dit kom daarop neer dat die oorgang tussen vs 23 en vs 24 waardeer moet word as 'n stuk literêre strategie wat gerig is op die implisiete leser - 'n literêre tegniek met bepaalde implikasies vir die identifisering van die implisiete outeur wat funksioneer as identifikasiemedium tussen homself en onder andere die reële outeur. Die verteller as literêre skepping van die reële outeur kan as strateeg die reële outeur se waardes vir die leser aanvaarbaar maak deur via ' $n$ implisiete outeur hom tot die leser te rig. ${ }^{41)}$ Só gesien, word die reële outeur in terme van die implisiete outeur beskryf, en omgekeerd.

Nieteenstaande die feit dat dieselfde verteller aan die woord is in die gedeelte tot en met vs 23 as dié in die gedeelte vanaf vs 24 , is dit duidelik dat die "ons" in vs $24 \mathrm{v}$ nie die "lieflingdissipel" kan wees na wie daar in vs 23 verwys word nie. Die "lieflingdissipel" is daarom klaarblyklik ook nie die reële outeur nie. In vs $24 a$ word die "lieflingdissipel" deur middel van vertellerskommentaar wel aangebied as die implisiete outeur en in vs $24 b$ (nog steeds deel van dieselfde vertellerskommentaar) as die betroubare draer van die waardes waarvoor die reële outeur staan, naamlik die selfgeloofwaardigheid van die apostoliese tradisie. Omdat vertellerskommentaar gewoonlik norme bevat hoe die vertelling gelees moet word, word die implisiete leser van die Johannesevangelie met vs 24 opgeroep om hom te identifiseer met die waardes waarvan die lieflingdissipel, as die implisiete outeur van die Johannesevangelie, die beliggamer en die draer is. Hierop word daar in die volgende studie verder ingegaan.

Om saam te vat, wat die outeurskap-vraagstuk met die oog op die resepsie van die Johannesevangelie betref: Omdat dit onmoontlik is dat die "lieflingdissipel" die reële outeur van vs $24 \mathrm{v}$ kon wees, is dit ook onmoontlik dat hy die reële outeur van die gedeelte in hoofstuk 21 tot en met vs 23 kon gewees het. En nie net ten opsigte van hoofstuk 21 nie. Dit is op grond van dieselfde oorweginge onmoontlik dat die "lieflingdissipel" die reële outeur van hoofstukke $1-20$ kon gewees het. Die rede hiervoor is dat die verwysing in $\mathrm{Jh}$ 19:35 dat die "lieflingdissipel" die "outeur" van die Johannesevangelie sou wees en dat sy getuienis waar is, nie anders hanteer kan word as die ander soortgelyke verwysing in Jh 21:24 nie. Jh 19:35 is net soos Jh 21:24 'n literêre tegniek van die verteller as manipulerende strateeg. Hierdie twee verse het nie betrekking op inligting wie die werklike, reële outeur van die Johannesevangelie is nie, maar as vertellerskommentaar wil dit vir die leser riglyne bied oor hoe die Johannesevangelie gelees moet word. 


\section{Gevolgtrekking}

Onș gevolgtrekking wat die outeurskap van die Johannesevangelie betref, kan soos volg saamgevat word:

Dit is opvallend dat die verwysing binne die tweede eeuse kerk na die Johannesevangelie as die werk van die apostel Johannes saamval met die wye kanonieke aanvaarding daarvan en sitering daaruit. Johannese "outeurskap" en kanonisiteit van die Johannesevangelie het in die vroeë kerk klaarblyklik met mekaar te doen. ${ }^{42}$ Vroeë kerklike kanonkriteria bevat egter nie hermeneutiese riglyne vir vandag nie. Die kanon van die kerk is 'n geloofsartikel.

Die reële outeur het in sy vertelling sy lesers via die verteller met die ware aard van Jesus se identiteit gekonfronteer deur hulle veral met twee karakters in die vertelling, Petrus en die "lieflingdissipel", respektiewelik negatief en positief te laat assosieer.

Die reële outeur van die Johannesevangelie is aan ons heeltemal onbekend en sy teologiese bedoeling kan alleen in terme van die waardes van die "lieflingdissipel" as die implisiete outeur beskrywe word.

Heelwaarskynlik was die "lieflingdissipel" (wie se historiese identiteit onrekonstrueerbaar is) in die skool-aktiwiteit van die Johannese gemeentekring " $n$ outoritatiewe figuur of ten minste die simbool van ' $n$ betroubare garant van die apostoliese tradisie. ${ }^{43}$ )

Hoewel dit vreemd op die oor mag klink, literêr gesien is die "lieflingdissipel" die "outeur" ën die "leser" van die Johannesevangelie. Maar nie in die sin van die reële outeur en die reële leser nie - 'n gelykstelling tussen hierdie twee buitetekstuele kategorieë sou normaalweg buitendien absurd wees. Die "lieflingdissipel" is die geïmpliseerde outeur sowel as die geïdealiseerde leser, want die Christologiese waardes wat die evangelis wil kommunikeer, word in die "lieflingdissipel" beliggaam.

Ten slotte, die vroeë kerklike tradisie dat die apostel Johannes, die seun van Sebedeus, die evangelis van die Johannesevangelie sou wees, het nie tot 'n adekwate interpretasie van die Johannesevangelie bygedra nie. Hierteenoor het die Johannese skool-teorie, gekombineer met sekere aspekte van Bultmann se literêre analise van die Johannesevangelie en die beklemtoning van die "lieflingdissipel" se literère handelingsfunksie, nuwe perspektiewe vir die interpretasie of resepsie van die Johannesevangelie as vertelling geopen.

\section{Interpretasie of resepsie}

In 'n sekere sin, in aansluiting by Van Luxemburg, Bal en Weststeijn, ${ }^{41)}$ onderskei ons ter wille van 'n bepaalde metodologiese rede tussen die terme "interpretasie" en "resepsie". Laasgenoemde woord herinner ons in hierdie konteks aan die resepsie-estetika as 'n moderne literatuurteoretiese benadering. Ons het reeds in die inleiding tot die artikel daarop gewys dat die "leser" in hierdie benadering op die voorgrond staan. "De lezer concretiseert een materiële tekst tot een tekst zoals hij of zij die begrijpt, ervaart en waardeert." ${ }^{\text {(45) Afge- }}$ 
sien daarvan dat so 'n siening tot "affective fallacy" kan lei, het dit ook bepaalde implikasies in die Bybelse hermeneutiek waar die Bybel as die boek van die kerk funksioneer. Dit raak dus nie net die gebruik van die Bybel nie, maar ook sy gesag. "Affective fallacy" is die gevolg van subjektivisme en subjektivisme is sedert die Reformasie, vir ten minste die eksegeet wat staan in hierdie tradisie, ' $n$ onding. Tog mag die beklemtoning van die rol van die leser in die hermeneutiek nie sonder meer as subjektivisme afgeskryf word nie. Dit is 'n fout wat dikwels in die kring van die Gereformeerde ortodoksie gemaak word. ${ }^{46)}$ Wanneer die eksegeet die leser se rol egter sien as dié in ' $n$ relasionele wisselwerking tussen die teks (en sy vorm) en die leser, en die "leser" sodoende ' $n$ teksgeoriënteerde konsep word, is dit duidelik dat dit die bedoeling is dat "affective fallacy" vermy wil word. In die inleiding tot die artikel het ons ook reeds die oortuiging vermeld dat ' $n$ inagneming van die literêre rol van die "outeur" een van die maniere is waarop die analise van die teks kan help om die leser-respons te bepaal. Dis in hierdie opsig waar die term "interpretasie" in onderskeid met "resepsie" ter sake word. "We beschouwen ... interpretatie als een bijzondere vorm van receptie. Onder interpretatie verstaan we hier een systematische teksverklaring. De interpreet streeft naar een adequate of bevredigende betekenistoekenning. "47) "Interpretasie", en nie "resepsie" nie, sou dus volgens hierdie definisie beskrywend wees vir 'n eksegese-proses wat onderneem word vanuit ' $n$ bepaalde teksteorie en kenteorie asmede 'n bepaalde kommunikatiewe doelwit (soos byvoorbeeld die prediking), binne die raamwerk van ' $n$ bepaalde metodologiese model, byvoorbeeld die vertellersperspektief-analise. ${ }^{18)}$ In hierdie proses, wat die rol van die leser betref, analiseer die eksegeet die leser-respons vanuit die verteller se ideologiese perspektief en literêre strategie, wat die gebruik van 'n geïmpliseerde outeur kan insluit. Só gesien, is dit nie die doelwit van die eksegeet om 'n verslag op te stel van die velerlei wyse waarop die betekenismoontlikhede van die betrokke teks deur verskillende (reële) lesers gekonkretiseer word nie, hoewel so 'n resepsie-verslag op sy tyd nuttig kan wees. Inteendeel, die interpreteerder strewe na 'n bevredigende en adekwate betekenistoekenning ten opsigte van die betrokke teks met die oog op 'n spesifieke kommunikatiewe doelwit.

Toegepas op die Johannesevangelie kom dit daarop neer dat die analise van die rol van die "lieflingdissipel", as (implisiete) "outeur" ên (ideale) "leser", só 'n poging tot die interpretasie van die Johannesevangelie sou wees. Hierdie onderneming word egter in ' $n$ volgende studie verder gevoer.

1. Kyk S R Suleiman, "Introduction: Varieties of audience-oriented criticism" in The reader in the text. Essays on audience and interpretation (Edited by S R Suleiman \& I Crosman), Princeton, N J. 1980, 3-45.

2. S Fish, /s there a text in this class? Cambridge 1980; vgl. ook J van Luxemburg. M Bal \& W $\mathrm{G}$ Weststeijn, In/eiding in de literatuurwetenschap, Coutinho 1983, 79v.

3. Kyk E D Hirsch, Validity in interpretation, New Haven/Yale 1967, 3;8.

4. W Iser, Der implizite Leser, München 1972; vgl. ook M de Jong, "Is Iser relevant?" in 
Resepsie-estetika/Aesthetics of reception (SAVAL Kongresreferate III), Bloemfontein/ Potchefstroom 1983, 21-32.

5. W C Booth, The rhetoric of fiction, Chicago/London 1961; vgl. ook D H Steenberg, "Die manipulerende rol van die implisiete outeur, met verwysing na Houd-Den-Bek" in Resepsie-estetika/Aesthetics of reception, a.w., 55 en S Chatman, Story and discourse. Narrative structure in fiction and film, Ithaca ${ }^{3} 1983,147-55$.

6. $\mathrm{H}$ van den Bergh, "De verteller als strateeg" in RT Segers (red), Lezen en laten lezen, s'Gravenhage 1979, 155.

7. Kyk ook Eusebius, Historia Ecc/esiastica V, 8, 4.

8. "Daarna (ná die Sinoptiese Evangelies - A G v A) het Johannes, die dissipel van die Here, hy wat ook teen die bors van Jesus gelê het ( $v$ gl. Jh 13:23 - A G $\vee A$ ), self ook die evangelie uitgegee, terwyl hy in Efese, van Asië, vertoef het".

9. W G Kümmel (neu bearbeitet), Ein/eitung in das Neue Testament (Begründet von P Feine und J Behm), Heidelberg 151967, 165.

10. Kyk Eusebius, a.w., V, 24,3.

11. Vertaling is onder verdenking; kyk Kümmel, a.w., 1967, 166.

12. Kyk Eusebius, a.w., V, $20,4$.

13. Ireneüs, Adversus haereses II, 33, 3 = Eusebius, a.w., III, 23,3.

14. Ireneüs, a.w., V, $33,3,4=$ Eusebius, a.w., III, 39,1 .

15. Eusebius, a.w., III, 39, 2.

16. Eusebius, a.w., III, 39, 4.

17. W G Kümmel, a.w., 1967, 169.

18. Vgl. ook W G Kümmel, a.W., 1967, 164.

19. P S Minear, "The original functions of John 21 ", JBL vol 102/1 (1983), 90 noot 17.

20. Kyk W G Kümmel, a.W., 1967, 171.

21. Vgl D M Smith, John (Proclamation Commentaries), Philadelphia ${ }^{31979,5 .}$

22. Kyk ook J L Martyn, "Glimpses into the history of the Johannine community. From its origin through the period of its life in which the Fourth Gospel was composed" in L'Évangile de Jean. Sources, rédaction, théologie (Par M de Jonge), Gembloux 1977, $149-75$.

23. Vgl. W S Vorster, "The Gospel of St John as language", Neotestamentica 6(1972), $19-27$

24. Vgl. W S Vorster, "De taal van het Nieuwe Testament" in Inleiding tot de studie van het Nieuwe Testament (Onder redactie van A F J Klijn), Kampen 1982, 32-42.

25. W G Kümmel, Die Theologie des Neuen Testaments nach seinen Hauptzeugen. Jesus. Paulus. Johannes. Göttingen 21972, 235.

26. Kyk o.a. E Ruckstuhl, "Johannine language and style. The question of their unity" in L'Evangile de Jean, a.w., 125-47.

27. R Bultmann, Das Evangelium des Johannes (Ergänzungsheft), Göttingen 1957, 369-70.

28. R Bultmann, a.w., 370 .

29. D M Smith, a.w., 1979, 62.

30. Kyk o.a. H Conzelmann, "Was von Anfang war", in Neutestamentliche Studien für Rudolf Bultmann (Beihefte zur ZNW 21), Berlyn 1957, 194-201.

31. R A Culpepper. The Johannine school. An investigation of the Johannine schoolhypothesis based on an investigation of the nature of ancient schoo/s, Missoula 1975, 262 vv.

32. Kyk ook W G Kümmel, a.w., 1972, 236 v.

33. Kyk o.a. J A du Rand, Die struktuur van die Christologie van die evangelie van Johannes Metodologiese oorwegings, Bloemfontein 1982, $11 \mathrm{v}$.

34. Kyk D M Smith, a.w., 63.

35. W G Kümmel, a.w., 1967, 162.

36. H Thyen, "Entwicklungen innerhalb der johanneischen Theologie und Kirche im Spiegel von Joh. 21 und der Lieblingsjüngertexte des Evangeliums", in L'Évangile de Jean, a.w., 259-99.

37. $M$ de Jonge, "The beloved disciple and the date of the Gospel of John" in Text and inter- 
pretation. (Studies in the New Testament presented to Matthew Black. Edited by E Best \& R McL Wilson), Cambridge 1979, 99-114.

38. P S Minear, a.w., 85-98.

39. Kyk ook $M$ de Jonge, a.w., 105.

40. Kyk ook o a W G Kümmel, a.w., 1967, 163.

41. Kyk ook J N Vorster, "Die geïmpliseerde leser van 'n oorredende teks" (Ongepubliseerde voordrag, Livtred-byeenkoms van die NTWSA, Universiteit van Pretoria, 26 Oktober 1984). 7.

42. Kyk ook D M Smith, a.w., 62.

43. Vgl. o.a. R Schnackenburg, "On the origin of the Fourth Gospel" in Jesus and man's hope (Edited by D G Miller \& D Y Hadidian), Pittsburgh 1970, 233-46.

44. J van Luxemburg, $M$ Bal \& $W G$ Weststeijn, a.w., $111 \mathrm{v}$.

45. J van Luxemburg, $M$ Bal \& W G Weststeijn, a.w., 112.

46. Vergelyk byvoorbeeld die kritiek wat uit die kring van die gereformeerde ortodoksie ("The message of Chicago" in RES News Exchange, August/September 1984, 28) gemaak word op die "relasionele waarheidsbegrip" soos uitgedruk in die GKN se rapport God met ons. Over de aard van het Schriftgezag (Special Kerkinformatie 113), Utrecht 1981

47. J van Luxemburg, $M$ Bal \& W G Weststeijn, a.w., 112.

48. Kyk A G van Aarde, "Die vertellersperspektief-analise. 'n Literatuur-teoretiese benadering in die eksegese van die evangelies". Hervormde Teologiese Studies vol 38, Aflw. 4, $58-62$. 